\title{
Analyzing the Linkage between Agricultural Exports and Agriculture's Share of Gross Domestic Products in South Africa
}

\author{
Mushoni B. Bulagi (Corresponding author) \\ Senior Researcher, Centre for Science, Technology and Innovation Indicators, Human \\ Science Research Council \\ Jan J. Hlongwane
}

Senior Lecturer, Department of Agricultural Economics and Animal Production, University of Limpopo

Abenet Belete

Professor, Senior Lecturer: Department of Agricultural Economics and Animal Production, University of Limpopo

Received: December 22, 2015 Accepted: January 6, 2016 Published: January 23, 2016 doi:10.5296/jas.v4i1.8918 URL: http://dx.doi.org/10.5296/jas.v4i1.8918

\begin{abstract}
The paper analyses the link between avocado, apple, mango and orange exports and agriculture's share of Gross Domestic Product in South Africa. The study used secondary time series data that covered a sample size of 20 years (1994 - 2014) of avocado, apple, mango and orange exports in South Africa. Two Stages Least Square models were used for data analysis. Empirical results for agricultural exports equation revealed that agricultural economic growth in South Africa was significant with a positive coefficient. Also a negative relationship between the Net Factor Income (NFI) and the agricultural exports in South Africa was noticed. Real Capital Investments had a significant positive coefficient. Consequently, results from agricultural economic growth equation revealed that agricultural exports were significant with a positive correlation. A relationship between NFI and agricultural GDP was also witnessed. Like other variables, Real Capital Investment was significant but negatively correlated.
\end{abstract}

Keywords: agricultural exports, agricultural GDP, exports policy, agricultural trade, South African agriculture 


\section{Introduction}

\subsection{Background}

South Africa's agricultural sector is dualistic: a developed commercial farming sector co-exists with a large number of small-scale farms. South African agriculture is increasingly export-oriented with approximately one third of total production exported. Although reforms of agricultural policies has also been initiated, changes in South African agriculture policies in the past decade have been shaped by substantial macroeconomic and social reforms implemented during the mid-1900s to date. According to (Organisation for Economic Co-operation and Development, 2006) such policies included the deregulation of the marketing of agricultural products, abolishing certain tax concessions favoring the sector, reductions in budgetary expenditure on the sector, land reform, and trade policy reform. The opening of the agricultural sector after 1996 placed South Africa among the world's exporters of agro-food products such as wine, fresh fruit and sugar. South Africa is also an important trader of agricultural exports in Africa. In the global market, Europe is by far the largest destination, absorbing almost one half of the South African agricultural exports. Imports were also growing but less rapidly than exports (DAFF, 2012).

The South African Gross Domestic Product (GDP) increased from 2.9\% to $3.1 \%$ while agriculture contributes less than $3 \%$ to the share of GDP (DAFF, 2012). Wine and fruit production has seen the most dynamic development in the past ten years with a large share of total output exported, mainly to Europe. Agricultural products, particularly those with export potential, have been viewed by many underdeveloped nations around the globe as playing a vital role in economic development. The debate on the relationship between agricultural export and agricultural GDP has exhibited considerable interest in the field of development economics. Several empirical studies (Xu, 1996; Tyler, 1981; Shirazi and Manap, 2004; Faridi, 2012) were conducted to assess the role of exports towards the economic growth of developing countries from various aspects. While the true measure of these nations' development needs to be expressed through improvements in the standard of living of the people, their economic growth plays a significant part in this process by providing increased per capita income, increased revenue for government sponsored social services and leading to export led-growth. Relatively recent studies [Tiffin and Irz (2006); Memon et al., (2008); Shombe (2008); Sanjuan-Lopez and Dawson (2010); Raza et al., (2012); Faridi (2012)], have their main emphasis on causality between export growth and economic growth. This has been adopted in a number of recent studies designed to assess whether or not individual countries exhibit evidence for export-led growth hypothesis using time series data. The major disadvantage of these causality test results is that the Granger or Sims tests used in these studies are only valid if the original time series are co-integrated.

The opportunity to expand exports is a key determinant of the prospects for economic growth in developing countries. Regardless of whether or not exports drive economic growth, one of the primary aims of any country's economic policy includes trade, industry policy and internationally competitive sectors which contribute to job creation. It is within this framework that the linkage between avocado, apple, mango and orange exports and agriculture's share of GDP needs to be studied and also its roles in economic development in South Africa need to be assessed. Literature [Katircioglu (2006); Shombe (2008), Khalafalla 
and Webb (2001)] on economic development and growth discusses the relationship between exports and economic growth. This group of studies found correlation between these two variables and better support an export led-growth hypothesis.

The role of agricultural exports to agriculture's share of Gross Domestic Product (GDP) in South Africa is of extreme importance and exhibit strong interest from all parts of the economy. Many believe that agriculture can salvage the declining economic growth under such global economic conditions. The decision to diversify and expand exports of these produce will improve the unstable South African economy. This is a result of the effect of agricultural export diversity and it's expectation to provide economic development and sustainable finances needed. It is necessary for the study to focus on an individual in order to account for all the factors that are truly unique to a nation's economy. Therefore, the study will help to shift the focus of avocado, apple, mango and orange growers to export more due to the international market demand for such produce.

\subsection{Purpose and objectives of the study}

The purpose of the study was to analyse the link between agricultural exports and agriculture's share of gross domestic products in South Africa. The specific objectives of the study were to :

(i) determine the correlation between avocado, apple, mango and orange exports and the agriculture's share of Gross Domestic Product in South Africa and

(ii) investigate the contribution of avocado, apple, mango and orange exports to agriculture's share of Gross Domestic Product in South Africa.

1.3 Hypotheses of the study

(i) there is no correlation between avocado, apple, mango and orange exports and the agriculture's share of Gross Domestic Product in South Africa and

(ii) there is no contribution of avocado, apple, mango and orange exports to agriculture's share of Gross Domestic Product in South Africa.

\section{Avocado, apple, mango and orange exports in South Africa}

In the past five years tonnes of avocado, apple, mango and orange have been exported to different destinations, and these exports face competition in the markets. 


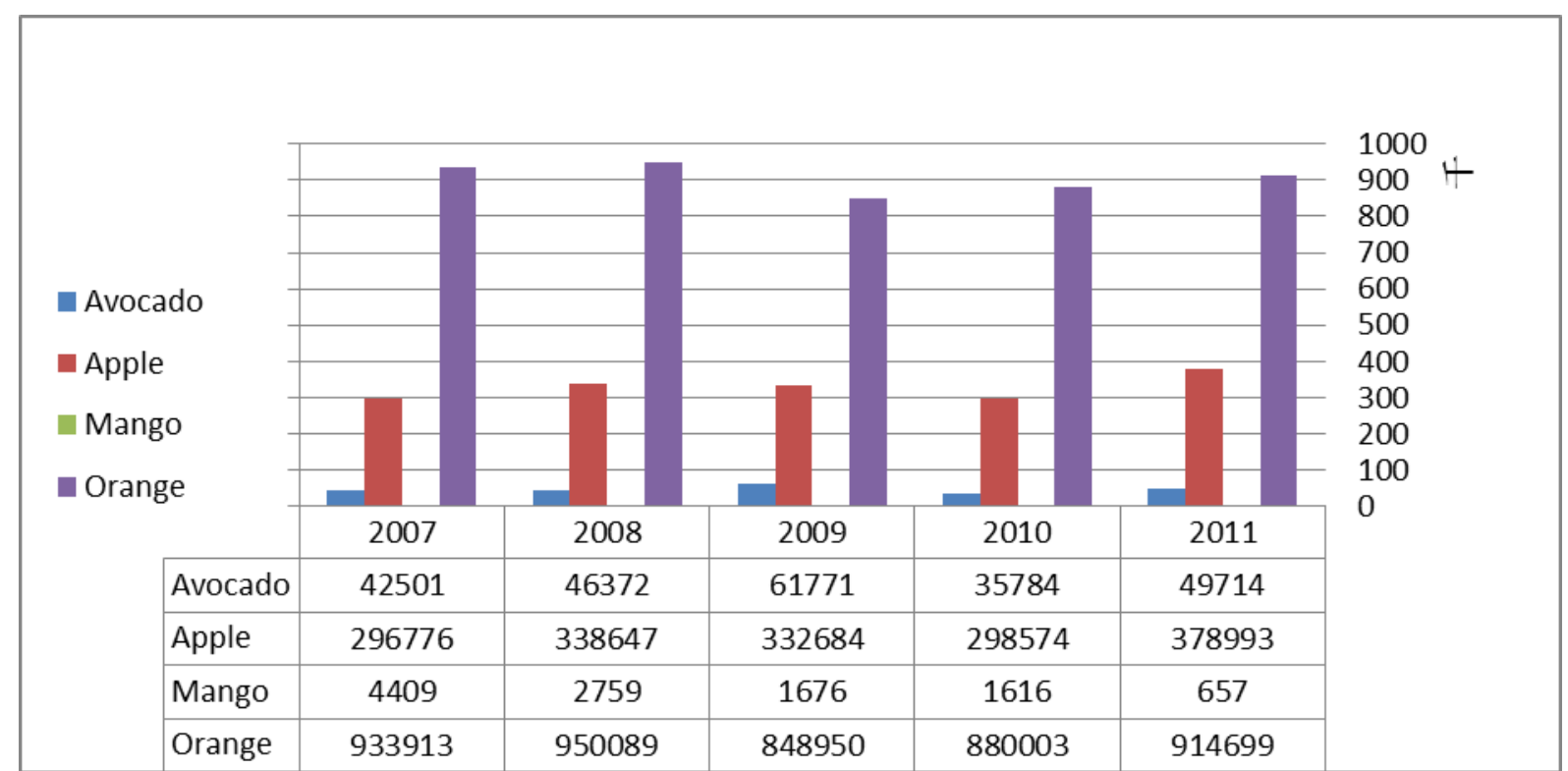

Figure 1. Avocado, apple, mango and orange exports in tonnes from 2007 to 2011

Source : DAFF (2012)

Figure 1 shows flactuating exported tonnes over the past five years and does not have room for mango exports due to low export volumes, with the highest tonnes reached in 2007. It is worthwhile to note that should the share of other exports increasing with lower volumes, avocado exports rise with very big volume due to favourable climatimacal conditions and its market share.

\section{Data and Methodology}

\subsection{Study area and sampling technique}

The study of the impact analysis of the linkage between avocado, apple, mango and orange exports to agriculture's share of Gross Domestic Products was conducted in South Africa. The study used the secondary time series data that were obtained from Department of Agriculture, Fishery and Forestry Statistical Directorate and Statistics South Africa. The study used a sample size of 20 years (1994 - 2014) of avocado, apple, mango and orange exports in South Africa. Data was broken into four sub sectors i.e. Agricultural exports, Agricultural Economic Growth, Net Factor Income and Real Capital Income. Agricultural exports covered avocado, apple, mango and orange exports. These exports were expressed physically in monetary value and tonnes. Agriculture GDP, NFI and INV were expressed in percentage. The data were lagged at two, to avoid stationary using the Augmented Dickey-Fuller test. This test was run independently from the models used to analyse data in order to show the ability of secondary time series data to address objectives of the study.

\subsection{Analytical technique}

The study used the Two-stage Least Square (2SLS) model to determine the relationship between avocado, apple, mango and orange exports and agriculture's share of Gross 


\section{$\Lambda$ Macrothink}

Journal of Agricultural Studies

ISSN 2166-0379

2016, Vol. 4, No. 1

Domestic Products in South Africa from 1994 to 2014. The Statistical Package for Social Sciences (SPSS) 22.0 was used to analyse. The 2SLS model assumes that agricultural economic growth is simultaneously determined along with avocado, apple, mango and orange exports. As proposed by Davidson and McKinnon (1981), the J-test was used in the process of model selection, and only statistically significant variables were included in the two stage least square system equation. This assures that the model is specifically tailored to suit the South African agricultural economic growth. The two stage least squares systems approach was used to estimate the equations in this study in order to avoid simultaneity bias. The selected model for this study has a system of two simultaneous equations determining agricultural economic growth and avocado, apple, mango and orange exports of South Africa.

General models

Avocado, apple, mango and orange exports equation:

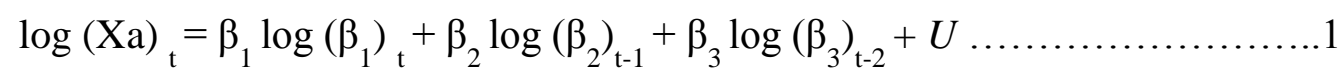

Agricultural economic growth equation:

$$
\log (\mathrm{AGE})_{\mathrm{t}}=\beta_{1} \log \left(\beta_{1}\right)_{\mathrm{t}}+\beta_{2} \log \left(\beta_{2}\right)_{\mathrm{t}-1}+\beta_{3} \log \left(\beta_{3}\right)_{\mathrm{t}-2}+U
$$

Specific models

Avocado, apple, mango and orange exports equation:

$$
\log (\mathrm{Xa})_{\mathrm{t}-1}=0+\mathrm{AGE} \log (\mathrm{AGE})_{\mathrm{t}}+\mathrm{NFI} \log (\mathrm{NFI})_{\mathrm{t}-1}+\mathrm{INV} \log (\mathrm{INV})_{\mathrm{t}-2}+U .
$$

Agricultural economic growth equation:

$$
\log (\mathrm{AGE})_{\mathrm{t}-2}=0+\mathrm{Xa} \log (\mathrm{Xa})_{\mathrm{t}-2}+\mathrm{NFI} \log (\mathrm{NFI})_{\mathrm{t}-2}+\mathrm{INV} \log (\mathrm{INV})_{\mathrm{t}-2}+U \ldots \ldots \ldots \ldots . .4
$$

Xa represents avocado, apple, mango and orange exports; AGE represents agricultural economic growth; NFI and INV represents Net Factor Income and Real Capital Investments which are all coefficients; $\mathrm{t}$ is the time factor and $U$ is the disturbance term.

\section{Empirical Results and Discussion}

Table 1. Correlation matrixes of agricultural GDP and agricultural exports

\begin{tabular}{|l|c|l|}
\hline Variables & Correlation Co-efficient & Significance(2-tailed) \\
\hline Avocado & $-0.558^{* *}$ & 0.001 \\
\hline GDP & 1.000 & 1.000 \\
\hline Apple & $-0.399^{* *}$ & 0.023 \\
\hline GDP & 1.000 & 1.000 \\
\hline Mango & $0.452^{*}$ & 0.010 \\
\hline GDP & 1.000 & 1.000 \\
\hline Orange & $-0.739^{* * *}$ & 0.000 \\
\hline
\end{tabular}

$*, * *, * * *$ Correlation is significant at $1 \%, 5 \%$ and $10 \%$ levels (2-tailed)

In table 1 above the direction of association that exists between avocado and agriculture's 
share of GDP was significant at $10 \%$. This implies a linear correlation between these variables such that when avocado exports increase the agricultural GDP will also increase or decrease thus supporting the export-led growth hypothesis. Avocado exports have a negative coefficient which implies that the avocado exports of the above produce have a negative influence on the agricultural GDP of South Africa. Due to higher volumes of apple exports across the borders, the share of apple exports towards agricultural GDP differs with the avocado's contribution. This is because of a significant correlation between apple exports and the agriculture's share of GDP; hence the export-led growth notion still holds true. These variables were significant at $5 \%$, which implied that when apple exports increase a decrease in agriculture's share of GDP is witnessed.

A very low quantity of mango exports goes over South African borders as a result mango exports make a limited contribution to the GDP. Table 1 above shows the direction of association that exists between mango exports and agriculture's share of GDP which was significant at $10 \%$. An increase in the mango exports will trigger an increase in agricultural GDP and this goes to support the export-led growth hypothesis. Orange exports attract most markets in international trade. In a season, higher volumes of oranges are exported across the borders; the share of orange exports towards agricultural GDP contribution was positive. This is because of a significant correlation between orange exports and the agriculture's share of GDP like other three produce. This supports the export-led growth hypothesis. Orange exports were significant at $10 \%$, which implies that when orange exports increase the agriculture's share of GDP will decrease.

Table 2. Empirical results of agricultural GDP equation

\begin{tabular}{|l|c|c|c|c|}
\hline Variables & Co-efficient & $\begin{array}{l}\text { Standard } \\
\text { Error }\end{array}$ & $\begin{array}{l}\text { Wald } \\
\text { statistics }\end{array}$ & Significance \\
\hline Xa & $0.463^{* *}$ & 0.422 & 1.095 & 0.040 \\
\hline NFI & 0.742 & 0.633 & 1.172 & 0.266 \\
\hline INV & $-0.032^{* * *}$ & 0.745 & -0.043 & 0.007 \\
\hline Constant & -0.038 & 0.190 & 0.199 & 0.846 \\
\hline - 2 Log likelihood & 12.39 \\
\hline Pseudo R square & \multicolumn{2}{|l}{} \\
\hline \% cases correctly predicted & $95 \%$ \\
\hline Chi - square & 20.50 \\
\hline
\end{tabular}

$*, * *, * * *$ represent significance at $1 \%, 5 \%$ and $10 \%$ respectively

Table 2 above shows that agricultural exports are significant at 5\% level, this denotes that when the exports increase the agricultural GDP will also increase hence supporting the export-led growth hypothesis. Agricultural exports have a positive coefficient which implies that the exports of the above produce have a positive influence on the agricultural GDP of South Africa. In most recent studies agricultural export was found to be a factor that matters most to the agricultural GDP all over the world. There is a positive relationship between the net factor income and the agricultural GDP of South Africa. Table 1 shows that this variable does not appear to be significant at any level. The implication of an increase in net factor income is that there will be an increase in the exports of mangoes from South Africa which also leads to an increase in the agricultural GDP. 


\section{$\triangle$ Macrothink}

Apple, avocado, mango and orange farmers desire results that earn them much needed foreign currency and to the economist, on the other hand, it would be the law of demand. Conversely; when the farmer is not exposed to international trade, which heightens exports, the possibilities of farming for exports and international trade are very slim. Real Captical Investment as a variable was significant at $10 \%$ and has a negative coefficient which means that money invested by farmers for exporting apple, avocado, mango and orange in South Africa has a negative influence on the agricultural GDP. This is a result of lack of other funds which can be used to export more products in the future and also a result of different investment decisions that may be taken.

Table 3. Empirical results of agricultural exports equation

\begin{tabular}{|l|l|l|l|l|}
\hline Variables & Co-efficient & $\begin{array}{l}\text { Standard } \\
\text { Error }\end{array}$ & $\begin{array}{l}\text { Wald } \\
\text { statistics }\end{array}$ & Significance \\
\hline AGE & $0.215^{* *}$ & 0.191 & 1.124 & 0.030 \\
\hline NFI & -0.002 & 0.276 & -0.006 & 0.995 \\
\hline INV & $0.237^{* * *}$ & 0.266 & 0.890 & 0.000 \\
\hline Constant & 0.771 & 0.787 & 0.980 & 0.346 \\
\hline - 2 Log likelihood & \multicolumn{2}{|c|}{18.46} \\
\hline Pseudo R square & \multicolumn{2}{|c|}{$51.6 \%$} \\
\hline \% cases correctly predicted & 6.62 \\
\hline Chi - square
\end{tabular}

$*, * *, * * *$ represent significance at $1 \%, 5 \%$ and $10 \%$ respectively

Increasing GDP is one of the major targets of almost every economy (Shombe, 2008). There are many ways which can be used to achieve economic growth, and to mention one, exports have received a notable attention in recent studies. Table 3 shows that the agricultural GDP of South Africa is significant at five percent level. This implies that an increase in the agricultural GDP results from an increase of agricultural exports in South Africa hence leading to the export-led growth hypothesis. The agricultural GDP of South Africa has a positive coefficient and it means that the country's agricultural GDP can somewhat benefit from the exports of avocados, apples, mangoes and oranges.

There is a negative relationship between the net factor income and the apple, avocado, mango and orange exports in South Africa. Table 3 above shows that this variable does not appear to be significant at any level. This implies that if the net factor income increases there will be a decrease in the exports of mangoes in South Africa hence a decline in the agricultural GDP. This will be a result of excessive spending of farmers that export apple, avocado, mangoes and orange in respect to other international markets which leads to a negative balance of payments hence a negative GDP. Most authors who found a positive relationship between exports instability and economic growth argue that if we assume risk-averse behaviour, uncertainty about export earnings can lead to a reduction in consumption and in turn, an increase in saving and investment and thus economic growth (Sinha, 1999). Furthermore, table 3 above shows that this variable is significant at ten percent and has a positive coefficient which means that money invested by farmers exporting mangoes in South Africa have a positive influence on the agricultural GDP. This will be a result of much needed interest and other benefits that are earned from other investments (physical and monetary 
from these exports).

The relationship between agricultural GDP and apple, avocado, mango and orange exports in South Africa was demonstrated by the estimated parameter for the independent agricultural exports variable in the GDP equation and by the estimated parameter for GDP growth in the agricultural exports. In the Two-Staged Least Square System Approach which estimated the agricultural GDP, it was found that agricultural export was positive and statistically significant at a level of five percent. According to this model, a five percent increase in agricultural exports would ultimately result in examined in a variety of ways. In this quest the agricultural exports equation was drawn into the study. This equation helped to analyse the link between agricultural exports and agriculture's share of GDP in South Africa. The estimation of two among all three variables was positive and significant at one and five percent while the other variable was negative and not significant at any level. The positive estimates for the agricultural GDP and the Real Capital Investments which were significant at ten percent and one percent and positive coefficients respectively.

The consistent positive relation suggests that the positive externalities generated by avocado, apple, mango and orange exports on the agricultural GDP increase when the share of avocado, apple, mango and orange exports increases also helped in not rejecting these two hypotheses. The NFI was negative and not consistent with prior expectations; however the coefficients were very small, implying that an increase in income remittance on agricultural GDP as a result of agricultural exports being negative will result in a direct role that was determined in the agricultural GDP equation. These outcomes draw serious conclusion. In responding to the last two hypotheses, it was found that agricultural exports in South Africa were influenced by other factors over the past 20 years. With the possible factor been higher rate of interest which makes it difficult for farmers to loan money to improve their exports.

The information of this nature is important for the analysis of agricultural economic development strategies in South Africa. The timing of this information is critical as South African policy makers now face major economic reforms in a quest for a more export oriented and stable agricultural economic development. As the South African government is under pressure to alter the UK Citrus ban, historical land claims and agricultural policies, understanding the impact of agricultural export for few quantities or exports on GDP growth will provide important information for policy analysis.

\section{Conclusions and Recommendation}

The results of this study show that the amount of avocado, apple, mango and orange exports was positively related to agricultural economic growth. Another point of interest in this study was that while avocado, apple, mango and orange exports are positive and significantly related, the magnitude of its coefficient is smaller than the coefficients of Real Capital Investments. This implies that the agricultural economic growth benefits more from an exports structure which is rich due to direct investments. It is in this framework that a positive correlation exists between agriculture economic growth and avocado, apple, mango and orange exports. It is recommended that investments opportunity in the agricultural sector need to be investigated because knowledge on such issue is very limited. There are reasons 
related to this notion which this study did not investigate, but this could be one of the important issues to investigate. The department of Agriculture, Forestry and Fishery and the private sector need to join hands and forge a mutual relationship to aid in developing an agricultural economy atmosphere which can be able to encourage and open doors for more exports than imports. This can also be done by subsidising farmers with capital to endure other cost.

\section{References}

Davidson, R., \& Mackinnon, J. G. (1981). Several Tests for Model Specification in the Presence of Alternative Hypotheses, Econometrica, Econometric Society, 49, 781 - 793.

DEPARTMENT OF AGRICULTURE, FISHERY AND FORESTRY (DAFF), (2012). Economic Review of the South African Agriculture. South Africa. Available at http://www.daff.gov.za/docs/statsinfo/EconReview2012.pdf [accessed :27/10/2015]

Faridi, M. Z. (2012). Contribution of Agricultural Exports to Economic Growth in Pakistan, Pakistan Journal of Commercial and Social Sciences, 6, 133 - 146.

Katircioglu, S. T. (2006). Causality between Agriculture and Economic Growth in a small nation under Political isolation: A case from North Cyprus. International Journal of Social Economics, 33, 331 - 343.

Khalafalla, K.Y., \& Webb, A. J. (2001). Export-led Growth and Structural Change: Evidence from Malaysia, Applied Economics, 33, 1703 - 1715.

Memon, M.H.,Baig, W. S., \& Ali, M. (2008). Causal Relationship between Exports and Agricultural GDP in Pakistan: Applied Economic Research Center, University of Karachi, paper No 11845.

ORGANISATION FOR ECONOMIC CO-OPERATIVE AND DEVELOPMENT (OECD), (2006). OECD Review of Agricultural Policies: South Africa, ISNB 92-64-03679-2. http://www.fanrpan.org/documents/d00456/OECD_review_agricultural_policies_SA.pdf [accessed: 27/10/2015]

Sanjuan-Lopez, A. I., \& Dawson, P. J. (2010). Agricultural Exports and Economic Growth in Developing Countries: A Panel Cointegration Approach. Journal of Agricultural Economics, $61,565-583$.

Shirazi, N.S., \& Manap, T. A. A. (2004). Export and Economic Growth Nexus: The case of Pakistan, Pakistan Development Review, 43, 563 - 581.

Shombe, N. H. (2008). Causality Relationships between Total Exports with Agricultural and Manufacturing GDP in Tanzania, Institute of Developing Economies, Discussion Paper No.136.

Sinha, D. (1999). Exports Instability, Investment and Economic growth in Asian Countries: A Time Series Analysis, Economic Growth Center, Yale University. Center Discussion Paper No. 799.

Tiffin, R., \& Irz, X. (2006). Is Agriculture the engine of Growth, Agricultural Economics, International Association of Agricultural Economists, 35, 79-89.

Tyler, W.G. (1981). Growth and Export Expansion in Developing Countries: some Empirical 
evidence. Journal of Development Economics, 9, 121 - 130.

Raza, S. A., Ali, Y., \& Mehboob, F. (2012). Role of Agriculture in Economic Growth of Pakistan. International Research Journal of Finance and economics, 83, 1450 - 2887.

$\mathrm{Xu}, \mathrm{Z}$. (1996). On the causality between export growth and GDP growth: An empirical investigation. The Review of International Economics, 4, 172-184.

\section{Copyright Disclaimer}

Copyright for this article is retained by the author(s), with first publication rights granted to the journal.

This is an open-access article distributed under the terms and conditions of the Creative Commons Attribution license (http://creativecommons.org/licenses/by/3.0/). 